\title{
Physicochemical interaction with faecal bacteria in characterisation of beach water quality, Gulf of Guinea, Ghana
}

Lailah Gifty Akita ( $D$ lailah.lailah@gmail.com )

University of Ghana https://orcid.org/0000-0002-1074-296X

Juegen Laudien

Alfred Wegener Institute for Marine and Polar Research: Alfred-Wegener-Institut Helmholtz-Zentrum fur Polar- und Meeresforschung

Charles Biney

Ecosystems Environmental Solutions

Mark Akrong

WRI: Water Research Institute

\section{Research Article}

Keywords: beach water quality, faecal bacteria pollution, physicochemical parameters, Atlantic Coast, ecosystem, and public health

Posted Date: June 28th, 2021

DOl: https://doi.org/10.21203/rs.3.rs-255121/v1

License: (c) (1) This work is licensed under a Creative Commons Attribution 4.0 International License. Read Full License

Version of Record: A version of this preprint was published at Environmental Science and Pollution Research on August 12th, 2021. See the published version at https://doi.org/10.1007/s11356-021-15432-x. 


\section{Abstract}

Human activities such as industrial and agricultural waste discharges directly in the coastal areas increasingly contribute to pollution in coastal waters of Western Africa. The study employed physicochemical and faecal analysis to understand water pollution along the coast of Ghana. The physicochemical parameter such as temperature, salinity, electrical conductivity, pH, dissolved oxygen concentration, dissolved oxygen saturation, total dissolved solids, and redox potential) were measured in situ while water samples were collected determination of total suspended solids, nutrients, chlorophyll-a, and faecal bacteria. The abundance of total coliforms (4061.6 $\pm 4159.14 \mathrm{CFU} / 100 \mathrm{ml}$ water), Escherichia coli, and Enterococcus spp. varied significantly $(\mathrm{p}<0.05)$ among the beaches. The high amount of faecal bacteria suggest microbial contamination, possible ecosystem, and health risks to water resource users. This baseline study provides evidence of coastal water contamination to improve beach water quality standards to ensure safe environmental health.

\section{Introduction}

Coastal water bodies are impacted through pollution, deteriorating urban sanitation, land use, and hydrological changes (Armah et al. 1997, Pommepuy et al. 2005, Shuval 2006, Stewart et al. 2008). The human activities in Ghana's urban coastal regions are increasingly contributing to coastal water pollution (Lawson 2014). About $50 \%$ of the world population lives in towns and cities within $100 \mathrm{~km}$ of the coast (Shuval 2006, Stewart et al. 2008). Many people do not have access to clean drinking water, and numerous people die of waterborne bacterial infections (e.g., cholera and typhoid) (Cabral 2010, Igobinosa \&Okoh 2009).

Ghana is a low-lying region (on average, 30 meters above sea level) and bordered by the Gulf of Guinea between $4^{\circ}$ and $12^{\circ} \mathrm{N}(\mathrm{Fig} .1$ ). The coastline is about $550 \mathrm{~km}$ long, and the continental shelf (about 75-120 meter deep) is narrow and covers an area of approximately $26,000 \mathrm{~km}^{2}$ (Armah \&Amlalo 1998, Lawson 2014). The Ghanaian coastal shore is categorized into the western, central, and eastern coastlines (Armah 1991, Ly 1980). The west coast covers $95 \mathrm{~km}$ of the stable shoreline and extends from Ghana's border with Côte d'Ivoire to the Ankobra River's estuary (Lamptey et al. 2010, Wiafe et al. 2013). The central zone includes $321 \mathrm{~km}$ of shoreline and extends from the Ankobra River's estuary, near Axim to Prampram on the eastern coast. The east zone encompasses $139 \mathrm{~km}$ of shoreline, which extends from Prampram to Aflao, at the border to the Republic of Togo and characterizes by sandy beaches with a central deltaic estuary and coastal lagoons (e.g., Keta Lagoon, Volta Estuary, and Songor Lagoon) (Lamptey et al. 2010, Wiafe et al. 2013).

The Gulf of Guinea coast resources serve as a source of seafood, recreational, educational, medicinal and an important social and economic value to the well-being of coastal communities. Major Hotels, fishing industries and two major habours, Tema and Takoradi are located along the coastal area of Ghana. The discharge of effluents without inadequate treatments into nearshore waters is critical environmental issue. Biological monitoring of coastal waters in Africa is inadequate compounded by lack of continuous oceanography monitoring observations. A short survey was conducted to characterize the beach water quality through physicochemical and microbacteria assessment of near shore waters of Ghana. The specific aim was to understand the influence of physicochemical drivers of spatial distribution of microbacteria in beach waters. The study reveals high bacterial loads along the coast of Ghana, a threat to public health and beach users and a useful baseline for further biomonitoring in the coast of Gulf of Guinea, West Africa region.

\section{Sampling And Analytical Methods}

\section{Sampling}

The ten beaches covers the eastern, central and western coastal region of Ghana (Figure 1). The Global Position System (Garmin etrex 10 Model) (Garmin Limited, Kansas, USA) (www.garmin.com) was used to record the coordinates of the beaches. Short survey of ecological integrity of randomized selected beaches along the coastal area of Ghana was carried out from 8 to 14 October 2016. The survey aims to understand the state of beach water quality. Horiba digital multiple parameter probe (Model U-52G 30M) (Horiba Company Limited, Japan) (www.Horiba.com) was used for in situ measurements of sea surface temperature, salinity, specific electrical conductivity, total dissolved solids, $\mathrm{pH}$, redox potential, dissolved oxygen concentration and saturation in near-shore beach waters. Each parameter was recorded three times and average computed. Three replicates of water samples from each beach were collected from 10 $\mathrm{cm}$ depth into $500 \mathrm{ml}$ clean plastic bottles for total solids, phosphate and nitrate analyses. Three replicates of water samples from each beach were also collected into $500 \mathrm{ml}$ plastic bottles covered with black polyethene bags for chlorophyll-a analyses. Ten water samples were collected into $500 \mathrm{ml}$ sterilized plastic bottles for bacterial examination at Laboratory at Council for Scientific and Industrial 
Research (CSIR)-Water Research Institute (WRI), Accra, Ghana. The water samples were stored on ice $\left(4^{\circ} \mathrm{C}\right)$ during transport to the laboratory. The analysis was carried out within 12 hours of collection.

\section{Analytical methods}

Water samples from each beach were prepared using standard methods for the examination of water and wastewater (APHA 2012). Phosphates and nutrients concentrations were determined using HACH spectrophotometer (Model DR/2010) (HACH Company, Loveland, Colorado, USA) (www. hach.com) (HACH 2012). Total suspended solids (TSS) were measured gravimetrically (APHA 2012). Chlorophylla extracted from $250 \mathrm{ml}$ of water samples in $96 \%$ ethanol and determined spectrophotometrically at specific wavelength method (Wintermans \&De Mots 1965). The principle behind the extraction method is that Chl-a is soluble in ethanol and absorbs light at certain wavelengths (Welschmeyer 1994). The wavelength $665 \mathrm{~nm}, 649 \mathrm{~nm}$ for pigments and $750 \mathrm{~nm}$ for turbidity correction (Lorenzen 1967). Chlorophyll-a (Chl-a) concentration ( $\mu \mathrm{g} / \mathrm{l})$ as an indicator of phytoplankton concentration in the water column (Hinga, 1995).

Bacteria examination of waters were prepared using standard methods and membrane filtration method (Millipore 1991 ). For the determination of total coliforms (Method APHA 9222A) and Escherichia coli (Method APHA 9260F), the filters were place on plates of solidified Cromocult Agar Media, following 18-24-hours incubation at $37 \underline{ \pm} 0.5^{\circ} \mathrm{C}$. Similarly, for the enumeration Enterococcus sp. (Method APHA 9230C), filters were placed on plates of Slanetz Bartley medium for $18-24$-hours at $44.5 \pm 0.5^{\circ} \mathrm{C}$. The bacteria in water are expressed in units of organisms per 100 milliliters of water. Total and faecal coliforms were determined by membrane filtration method using MEndo-Agar Les (Difco) at $37^{\circ} \mathrm{C}$ and on MFC Agar at $44^{\circ} \mathrm{C}$, respectively (Cabral 2010). The medium contains a fluorogen that reacts with galactosidase in total coliforms and a chromogen that reacts with glucoronidase in Escherichia coli. The medium contains a chromagen that reacts with the enzyme glucosidase in Enterococcus sp. (Ferretti et al. 2011, Haugland et al. 2005). With the aid of colony counter, purple and blue colonies were counted as total coliforms, only blue colonies counted as Escherichia coli, and pinkish to red colonies counted as Enterococcus sp. colonies. The counts of total coliforms, Escherichia coli and Enteroccocus are expressed in colony forming units (CFU) per $100 \mathrm{ml}$ of water.

\section{Statistical analysis}

Statistical analysis such as mean, maximum and minimum along with analysis of variance coupled with correlation analysis using Paleontological statistical software, PAST 3 (Hammer et al. 2001) and statistical package for social sciences version 21.0 (SPSS 21.0) (Leech et al. 2011). Correlation coefficients at 0.05 and 0.01 levels were adopted. Pearson correlation coefficient (r) close to 1 was considered a better indicator of a strong association (Kinnear \&Gray 1999). The physicochemical parameters were square root transformed were classified by clustering of samples based on Euclidean distance. The abundance of bacteria were log-transformed [In(x \pm 1$)]$ (Bellier et al. 2012, Bray \&Curtis 1957, Legendre \&Gallagher 2001). Principal component analysis (PCA) were carried to established similarity and source of variation. Interactive selective forward selection in redundancy analysis detected a subset of physicochemical variables which best explain the bacteria matrix(Šmilauer \&Lepš 2014, ter Braak \&Verdonschot 1995). The Monte-Carlo permutation test ( $a=0.05 ; 999$ permutations) was adopted and performed using the Canoco software version 5.03 (Šmilauer \&Lepš 2014).

\section{Results}

The sea surface temperature, $\mathrm{pH}$, dissolved oxygen concentration and saturation, total dissolved solids, redox potential and nitrate satisfied the normal distribution and were subjected to one-way analysis of variance (ANOVA). These physicochemical variables do not significantly $(p>0.05)$ differ among the beaches. The ranged and mean are summarized in Table 2. High loads of total coliforms, Escherichia coli and Enterococcus sp. were found in beach waters along the coast of Ghana (Table 3). Maximum bacterial loads occur in Densu, Kpeshi and Ghana Togo boarder, while minimum levels occur in Anyanui beach. 
Table 2

Physicochemical parameters of coastal beaches in Ghana.

\begin{tabular}{|c|c|c|c|c|c|c|c|c|c|c|c|c|}
\hline Beaches & $\begin{array}{l}\text { Temp. } \\
\left({ }^{\circ} \mathrm{C}\right)\end{array}$ & $\begin{array}{l}\mathrm{EC} \\
(\mathrm{mS} / \mathrm{cm})\end{array}$ & $\begin{array}{l}\text { Sal } \\
\text { (PSU) }\end{array}$ & $\mathrm{pH}$ & $\begin{array}{l}02 \\
(\mathrm{mg} / \mathrm{L})\end{array}$ & $\begin{array}{l}02 \text { Sat } \\
(\%)\end{array}$ & $\begin{array}{l}\text { TDS } \\
(\mathrm{mg} / \mathrm{L})\end{array}$ & $\begin{array}{l}\text { TSS } \\
\text { (g/L) }\end{array}$ & $\begin{array}{l}\text { Eh } \\
(\mathrm{mV})\end{array}$ & $\begin{array}{l}\text { Phos } \\
\text { (mg/L) }\end{array}$ & $\begin{array}{l}\text { Nit } \\
(\mathrm{mg} / \mathrm{L})\end{array}$ & $\begin{array}{l}\text { Chl a } \\
(\mu g / L)\end{array}$ \\
\hline Gh- Côte & 29.24 & 43.04 & 27.52 & 8.33 & 6.40 & 85.10 & 21.52 & 4.00 & 83.50 & 0.06 & 1.97 & 2.61 \\
\hline Domunli & 27.53 & 49.39 & 30.57 & 9.05 & 5.06 & 75.00 & 23.57 & 7.00 & 61.83 & 0.04 & 2.10 & 2.26 \\
\hline Esiama & 27.47 & 43.50 & 27.95 & 8.03 & 3.80 & 55.80 & 21.74 & 23.00 & 194.40 & 0.25 & 2.77 & 2.88 \\
\hline Aboadzi & 26.94 & 48.76 & 31.75 & 8.66 & 4.01 & 59.61 & 24.36 & 7.00 & 163.00 & 0.12 & 2.30 & 2.64 \\
\hline Amisa & 28.20 & 33.13 & 21.00 & 8.70 & 3.68 & 52.00 & 16.57 & 76.33 & 109.57 & 0.54 & 3.57 & 2.61 \\
\hline Muni & 30.82 & 41.85 & 76.67 & 9.20 & 4.33 & 65.80 & 20.94 & 10.33 & 217.20 & 0.37 & 2.17 & 0.43 \\
\hline Densu & 30.74 & 52.60 & 34.70 & 8.30 & 6.44 & 109.60 & 31.60 & 10.67 & 194.70 & 0.16 & 3.27 & 1.23 \\
\hline Kpeshi & 28.27 & 50.23 & 32.81 & 8.75 & 3.69 & 55.90 & 25.09 & 18.67 & 265.00 & 0.16 & 2.73 & 1.69 \\
\hline Anyanui & 29.36 & 23.41 & 14.01 & 8.56 & 6.17 & 86.90 & 11.71 & 13.00 & 134.90 & 0.07 & 1.63 & 2.44 \\
\hline Gh-Togo & 29.51 & 49.21 & 33.01 & 8.80 & 4.85 & 74.50 & 24.61 & 12.00 & 158.20 & 0.08 & 2.53 & 6.13 \\
\hline $\begin{array}{l}\text { Mean } \pm \\
\text { SD }\end{array}$ & $\begin{array}{l}28.81 \\
\pm 1.4\end{array}$ & $\begin{array}{l}43.51 \pm \\
9.1\end{array}$ & $\begin{array}{l}33.00 \\
\pm 16.6\end{array}$ & $\begin{array}{l}8.64 \\
\pm 0.4\end{array}$ & $\begin{array}{l}4.84 \pm \\
1.1\end{array}$ & $\begin{array}{l}72.02 \\
\pm 18.1\end{array}$ & $\begin{array}{l}22.17 \\
\pm 5.3\end{array}$ & $\begin{array}{l}18.20 \\
\pm 21.2\end{array}$ & $\begin{array}{l}158.23 \\
\pm 62.7\end{array}$ & $\begin{array}{l}0.18 \pm \\
0.2\end{array}$ & $\begin{array}{l}2.50 \pm \\
0.6\end{array}$ & $\begin{array}{l}2.49 \\
\pm 1.5\end{array}$ \\
\hline Minimum & 26.94 & 23.41 & 14.01 & 8.03 & 3.68 & 52.00 & 11.71 & 4.00 & 61.83 & 0.04 & 1.63 & 0.43 \\
\hline Maximum & 30.82 & 52.60 & 76.67 & 9.20 & 6.44 & 109.60 & 31.60 & 76.33 & 265.00 & 0.54 & 3.57 & 6.13 \\
\hline
\end{tabular}

Table 3

Microbial contamination in beach waters, Gulf of Guinea, Ghana.

\begin{tabular}{|c|c|c|c|}
\hline Beaches & $\begin{array}{l}\text { TC_w } \\
\text { (CFU/100 ml) }\end{array}$ & $\begin{array}{l}\text { E. coli_w } \\
\text { (CFU/100 ml) }\end{array}$ & $\begin{array}{l}\text { Ent._sp_w } \\
\text { (CFU/100 ml) }\end{array}$ \\
\hline Gh-Côte & 3720 & 50 & 10 \\
\hline Domuli & 4650 & 220 & 1 \\
\hline Esiama & 1395 & 55 & 35 \\
\hline Aboadzi & 2790 & 360 & 5 \\
\hline Amisa & 5115 & 410 & 285 \\
\hline Muni & 420 & 120 & 30 \\
\hline Densu & 11160 & 5580 & 5580 \\
\hline Kpeshi & 11160 & 240 & 100 \\
\hline Anyanui & 36 & 1 & 0 \\
\hline Gh-Togo & 170 & 20 & 110 \\
\hline Mean \pm SD & $4061 \pm 4159.14$ & $705.60 \pm 1718.58$ & $615.60 \pm 1746.50$ \\
\hline Minimum & 36.00 & 1.00 & 0.00 \\
\hline Maximum & $11,160.00$ & $5,580.00$ & $5,580.00$ \\
\hline
\end{tabular}

Principal components analysis showed spatial grouping of beaches based on physicochemical variables (Fig. 4A). The first and second axes contributed to $59.43 \%$ of total variation in grouping of four clusters of beaches:(i) Anyanui; (ii) Ghana Côte d'Ivoire and Domonli (iii) 
Aboadzi, Kpeshi, Densu, Ghana-Togo border, and (iv) Amisa, Esiama and Muni (Fig. 2).

A combination of physicochemical and bacteria data showed four groups of beaches with different levels of contamination mainly (i) cluster 1; Kpeshi (total coliform and, Escherichia coli most contaminated site); (ii) cluster 2; Ghana Côte d'Ivoire, Domonli and Aboadzi (more oxygenated and low contaminated sites); (iii) cluster 3; Esiama, Muni,Anyanui and Ghana-Togo border and (iv)cluster 4; Amisa and Densu (Fig. 3).

Redundancy analysis (RDA) indicated that environmental variables accounts for $72.42 \%$ of variation in spatial distribution of bacteria. Nitrate and total dissolved solids significantly $(\mathrm{p}<0.05)$ influenced the spatial distribution of total coliforms, Escherichia coli and Enterococcus sp. in the coastal beaches of Ghana (Table 4).

Table 4

Key physicochemical variables influencing the spatial distribution of microbial communities in coastal beaches in Ghana.

\begin{tabular}{|llllll|}
\hline Parameter & Explains \% & Contribution \% & pseudo-F & P & P(adj) \\
\hline Nitrates & 55.3 & 55.3 & 9.9 & 0.002 & 0.024 \\
\hline Total dissolved solids & 17.2 & 17.2 & 4.4 & 0.017 & 0.102 \\
\hline
\end{tabular}

Salinity significantly positively correlated with electrical conductivity $(r=0.995, p=0.000)$ and total dissolved solids $(p=0.956, p=$ 0.000). Dissolved oxygen concentration and saturation were significantly positively correlated $(r=0.942, p=0.000)$. Total suspended solids significantly positively correlated with phosphate $(r=0.818, p=0.004)$ and nitrates $(r=0.694, p=0.026)$. There is a significant positive correlation $(r=0.633, p=0.049)$ between Escherichia coli and total coliforms. There is positive significant $(r=0.997, p=0.000)$ correlation between Escherichia coli and Enterococcus sp. Escherichia coli positive significantly correlated $(r=0.662, p=0.037)$ with dissolved oxygen concentration, whereas Enterococcus sp. showed positive significant correlation with dissolved oxygen saturation ( $\mathrm{r}=$ $0.678, p=0.031)$. A positive significant negative correlation exists between Escherichia coli $(r=-0.698, p=0.026)$ and Enterococcus sp. ( $r$ $=-0.704, p=0.023$ ) with total dissolved solids.

\section{Discussion}

High bacterial loads occurs in beaches (e.g., Densu, Kpeshi and Ghana-Togo boarder) (Table 3) within coastal zones characterized by increased human activities such as densely populated coastal communities, industrialization, tourisms, beach Resorts, transboundary, swimming and fishing activities. While minimum bacteria load occur in Anyanui beach which is characterized by less populated fishing communities in the eastern coast of Ghana.

Principal components analysis indicated the beaches can be classified into four major clusters based on influential physicochemical parameters:(i) cluster 1; Anyanui beach located in the eastern coast is influence by freshwater flow from Volta River leading to low saline condition and controlled by chlorophyll-a concentration (ii) cluster 2; Ghana Côte d'Ivoire and Domonli beaches are situated in western coast and mostly influenced by high oxygenated sea waters (iii) cluster 3; Aboadzi, Kpeshi, Densu, Ghana-Togo border beaches are located in western-central-eastern coast and characterized by increased electrical conductivity, salinity, total dissolved solids and $\mathrm{pH}$; and (iv) cluster 4; Amisa, Esiama and Muni beaches are situated in the central zone and characterized by high total suspended solids, phosphate and nitrates and redox potential (Fig. 2). The grouping of the beaches shows similar characteristics in their physicochemical composition of water quality.

The combination of physicochemical and bacteria data showed (Fig. 3) showed four major groups of beaches, mainly (i) Cluster 1; Kpeshi beach is major contaminated beach with high loads of total coliform and Escherichia coli. The Kpeshi beach is located at central of coast in the Greater-Accra region, Ghana. The beach is tourism center with two major hotels, La Beach Hotel and La Palm Hotel and the location is densely populated communities along the coast. The beach swimmers and discharge of waste by these hotels may have contributed to contamination of beach water with high bacterial loads; (ii) cluster 2; Ghana Côte d'Ivoire, Domonli and Aboadzi less contaminated beaches characterized by oxygenation. These beaches are located in western region where the population may be low and less frequent beach users and hotels (iii) cluster 3; Esiama, Muni, Anyanui and Ghana-Togo border beaches with moderated contaminated beaches characterized by chlorophyll-a concentration may have minimal human impact (iv) cluster 4; Amisa and Densu beaches with second major contaminated chacteracterised by Enterroccus sp. and nitrates. Densu beach is situated in area with high populated coastal vicinity and adjoining Densu beach Restort and Bojo beach coupled with connection to Densu estuary and subsequent Densu river. The Amisa Beach is connected with Amisa estuaries and connecting Amisa River. There is increasing human 
activities of fish farming, animal husbandry, water transportation in theses coastal systems which can cause increased in nutrients and bacteria load.

Nitrated and total dissolved solids significantly $(\mathrm{p}<0.05)$ drive the spatial distribution of bacteria in beach water $($ Table 3$)$. Enterococcus is mostly abundant in Esiama beach influenced by nitrated enrichment of the sea water. Whereas total coliforms and Escherichia coli abundant in Densu and Kpeshi beaches influenced by high levels of total dissolved solids of the seawater (Fig. 4). The correlation shows the linearity between salinity, conductivity and total dissolved solids. There is also significant linear association among the bacteria. The correlation between physiochemical and bacteria is confirmed by the principal component ordination

The lowest temperature $\left(26.94^{\circ} \mathrm{C}\right)$ was recorded at Aboadzi beach in western coast and the highest $\left(30.82^{\circ} \mathrm{C}\right)$ at Kpeshi beach in the central zone. Sea surface water temperature along the coast of Ghana ranged from 25.0 to $28.7^{\circ} \mathrm{C}$ with mean $\pm \mathrm{SD} 26.9 \pm 1.28^{\circ} \mathrm{C}$, and Chorkor beach ranges from 24.5 to $28.7^{\circ} \mathrm{C}$ with mean \pm SD $27.2 \pm 1.32{ }^{\circ} \mathrm{C}$ (Akita et al. 2014). Ghana is situated in the tropical equatorial climate belt with annual mean temperature between $25^{\circ} \mathrm{C}$ and $36^{\circ} \mathrm{C}$ (Allersma \&Tilma 1993). In this region the sea surface water temperature only varies marginal throughout the year (Biney 1982,1993). The coastal waters are thermally stratified with a well-mixed layer of warm $\left(25^{\circ} \mathrm{C}-36^{\circ} \mathrm{C}\right)$, low salinity water of 33.67-34.22 PSU in 30-40 $\mathrm{m}$ above a sharp thermocline (Mensah \&Anang 1998). Salinity of 35.05-35.38 PSU below the thermocline at 60-80 depth. During upwelling, the thermocline weakens and rises to the surface resulting in vertically homogeneous salinity profile above the shelf (Mensah \&Anang 1998). The lowest salinity (14.01 PSU scale) was recorded at Anyanui beach in the eastern coast due to freshwater intrusion from Volta River at Lower Volta Lake which also connects to Anyanui Lagoon, whereas the highest (34.70 PSU scale) in Densu beach in the central coast. Marine waters have a much higher conductivity than fresh to estuarine, ranged from 20.0 to $40.0 \mathrm{mS} / \mathrm{cm}$ ). Salinity of sea water is normally 36 PSU scale. The salinity of coastal beach waters in Ghana ranged from 33.5 to 37.9 (PSU scale) with mean \pm SDvalue $36.6 \pm 1.53$ (e.g., for La beach) and from 34.5 to 38.0 (PSU scale) with mean \pm SDvalue $36.7 \pm 1.21$ (e.g., for La beach) (Akita et al. 2014). The lowest (8.30) pH was recorded in Esiama beach and the highest (9.05) at Domunli beach. The EU has set protection limits of pH ranged from 6 to 9 as harmless for fisheries and aquatic life (Chapman 1996). The pH values fall within the $\mathrm{pH}$ ranged between 6 and 9 for natural waters and pH of 8.30 for sea water (Stumn \&Morgan 1981). The lowest (3.68 mg/l) dissolved oxygen concentration (DO) was recorded in Amisa beach and the highest $(6.44 \mathrm{mg} / \mathrm{L})$ at Densu beach. The nature of beach morphodynamics and hydrodynamic conditions may play role in circulation system of beach. Dissolved oxygen concentration is $7.0 \mathrm{mg} / \mathrm{l}$ for tropical surface waters (Biney 1993, Clark 2000) and unpolluted waterbodies of 8.0 to $10.0 \mathrm{mg} / \mathrm{l}$ at $25^{\circ} \mathrm{C}$ (DFID 1999). Dissolved oxygen concentration is another important environmental variable used for water quality controls. Adequate oxygen maintains the biological life of the aquatic ecosystems. Dissolved oxygen concentration of 4-5 $(\mathrm{mg} / \mathrm{L})$ can sustain aquatic life. But below $5.0(\mathrm{mg} / \mathrm{L})$ may indicates high microbial activity and can adversely affects aquatic life (DFID 1999, Stumn \&Morgan 1981). In extreme situations, decrease dissolve oxygen levels can lead to anoxic conditions, fish kills and odors resulting from anaerobic conditions (DFID 1999, Stumn \&Morgan 1981). The lowest (61.80 mV) redox potential was recorded in Domunli beach and the highest $(265.00 \mathrm{mV})$ at Kpeshi beach. A low redox potential corresponds to high pH as observed in Domunli beach. Higher redox potential means anoxic conditions as observed in Kpeshi. The redox potential for natural waters ranged from 500 to $600 \mathrm{mV}$ (Stumn \&Morgan 1981, Wetzel 2001). With depletion of oxygen, the redox potential decreased to 0 to $200 \mathrm{mV}$ (Stumn \&Morgan 1981, Wetzel 2001). The lowest total dissolved solids (11.71 mg/L) concentration was recorded at Anyanui beach and the highest $(31.60 \mathrm{mg} / \mathrm{L})$ at Densu beach. The lowest total suspended solids $(4.00 \mathrm{~g} / \mathrm{L})$ concentration was recorded at the Ghana- Côte d'Ivoire, border beach and the highest $(76.33 \mathrm{~g} / \mathrm{L}$ ) at Amisa beach which is connected to the Amisa Estuary, has tidal mixing and a large fishing industry. These activities may results in resuspension of minerals and salt particles through tidal influx and bottom trawling. High total dissolved solids in water originate from natural sources, urban and agricultural run-off, sewage discharges and industrial wastewater. The lowest phosphate $(0.04 \mathrm{mg} / \mathrm{l})$ concentration was recorded in Domunli beach and the highest $(0.54 \mathrm{mg} / \mathrm{L})$ at Amisa beach. The mean phosphate concentration of $(0.18 \pm 0.16 \mathrm{mg} / \mathrm{L}$ ) is higher concentration in unpolluted, natural waters (ranged from 0.005 to 0.020 mg/L) (Biney 1993, Clark 2000) (Chapman 1996)., Phosphate concentration is as low as $0.001 \mathrm{mg} / \mathrm{L}$ in some pristine waters (Chapman 1996)... Phosphate is the limiting nutrient for algal growth and therefore controls the primary productivity of a surface water body (Paerl et al. 2011). High concentrations of phosphate may indicate the presence of pollution and are largely responsible for eutrophic conditions (Omoike \&Vanloon 1999, Saad \&Younes 2006). The lowest nitrate (1.63 mg/L) concentration was recorded at Anyanui beach and the highest $(3.57 \mathrm{mg} / \mathrm{L})$ at Amisa beach. Nitrates in coastal beach waters of Ghana ranged from 0.5 to 0.25 to $1.8 \mathrm{mg} / \mathrm{L}$ in coastal waters of Ghana (Akita et al. 2014, Biney \&Asmah 2010). Low nitrates occurs in unpolluted waters (Jaji et al. 2007). Nitrates is the most highly oxidised form of nitrogen compounds present in surface waters (Igobinosa \&Okoh 2009). Nitrogen fixing bacteria and algae convert free nitrogen gas $\left(\mathrm{N}_{2}\right)$ into nitrates $\left(\mathrm{NO}_{3}{ }^{-}\right)$(Igobinosa \&Okoh 2009). Nitrogen waste products such as urea and uric acid are eventually converted to ammonia. The ammonia is then utilized by nitrate bacteria to form nitrites $\left(\mathrm{NO}_{2}{ }^{-}\right)$, which are in turn are converted into nitrate. Phosphates and nitrates essential nutrients necessary for primary production and naturally replenished by 
river run-off (Correl 1998, Sharpley et al. 2013). Phosphates and nitrates are limiting nutrients for plant growth (Paerl \&Huisman 2008). However, excess nutrients leads to phytoplankton blooms process often term as eutrophication (Kennish 2001, Nixon 1995, Smith \&Schindler 2009). The major proportion of phosphate are transported to the aquatic environment from cultivated land usually in particulate form through erosion and leaching transports relatively little soluble $\mathrm{P}$, as $\mathrm{P}$ is strongly adsorbed on clay particles (Carpenter et al. 1998, Elser et al. 2007, Sharpley et al. 2013).

The trophic state of beach water is classified as an ultra-oligotrophic to mesotrophic state based on chlorophyll-a concentration ( 0.43 to $6.13 \mu \mathrm{g} / \mathrm{LI}$ Chlorophyll-a concentration in nears-shore coastal beach waters of Ghana ranged Chorkor beach (Akita et al. 2014). Chlorophyll-a concentration ranges from 0.10 to $3.80 \mathrm{mg} / \mathrm{L}$ (average $1.39 \pm 0.84$ ) in coastal waters of Caspian Sea. Very low and high levels of Chlorophyll-a concentration can be harmful to marine biota (Jamshidi \&Abu Bakar 2011). Chlorophyll-a concentration act as an indicator of phytoplankton abundance and biomass in coastal ecosystems (Hinga et al. 1995, Monbet 1992). (Boyer et al. 2009, Bucci et al. 2012, Möller \&Scharf 1986). Chlorophyll-a concentration provide an estimates of phytoplankton biomass and thus productivity of a water body (Boyer et al. 2009, Jamshidi et al. 2010, Tripathy et al. 2005, UNESCO 1994). Eutrophication is associated with increased phytoplankton blooms and increased primary production (Wellman et al. 2002). A positive relationship was found between the Chl-a concentration in the swash zone and biomass and numbers of macrofaunal species nutrition (Lastra et al. 2006).

\section{Microbial water quality}

The abundance (Table 1) of total coliforms Escherichia coli and Enteroccocus is low in Anyanui beach and the highest at Densu and Kpeshi beaches. The small communities have contributed low contamination at Anyanui beach. Whereas, Densu and Kpeshi beaches are characterized by densely populated human settlements, farming surrounding catchments estuaries, large industries, tourisms, beach resorts, hotels, large coastal fishing communities and popular sites for beach swimmers. The possible contamination sources include untreated disposal of human and animal waste and runoff from agricultural farmlands may affect the beach water quality. In the southeast Nigeria, maximum bacterial colony count (up to $60000 \mathrm{CFU} / 100 \mathrm{ml}$ ) and largest variability were found in mesotidal estuaries and adjoining near-shore waters (Anita \&Showell 1997). In this study is limitation and variability was not evaluated due to 10-day short survey. However, the detection of Escherichia coli and Enteroccocus sp. in the coastal beach waters in Ghana provide evidence of faecal pollution, possibly from animal and human waste discharges. Total coliforms are found in animal intestines, in sediment on vegetation and in industrial waste. Escherichia coli often known as faecal coliform is found in natural inhabitant of the gastrointestinal tract of warmblooded animals and a direct evidence of faecal contamination. Faecal streptococci are found in faeces, however, some species live on plants and in sediment. Enterococcus sp. are a subset of faecal streptococci and commonly present in the faeces of warmblooded animals. Enterococcus are more persistent in water than coliforms. They provide a different assessment of the transport of faecal contamination in water than coliforms because of their different shape and survival rate (USEPA 2002). The presence of these faecal bacteria in marine waters can indicate the possible presence of disease causing bacteria, virus and protozoans (Crowther et al. 2001, Solic \&Krstulovic 1992). These pathogens may pose health risks to fisher folks and beach swimmers and sea food consumption. Faecal bacteria indicate a pollution caused human and animal waste discharges (Savage 1905, Sayler et al. 1975, Schroeder \&Wuertz 2003). Escherichia coli is mostly common in fresh and estuarine waters, whereas Enterococcus sp. is common in marine waters, good bioindicators of faecal contamination (Pachepsky \&Shelton 2011). Agriculture runoff and domestic sewage waste water are often associated with high loads of bacteria (Schroeder \&Wuertz 2003, Solo-Gabriele et al. 2000). Physicochemical variables such as salinity, temperature, nutrients and light, influence the survival and sometimes the proliferation of pathogens and bacteria (Cabral 2010, Pommepuy et al. 2005). The faecal bacteria are often used to detect water pollution (Odonkor \&Ampofo 2013). Microbial contamination is a growing concern for environmental and human health (Odonkor \&Ampofo 2013). Total coliform, Escherichia coli and Enterococcus $s p$. bacteria are used to indicate pathogens of faecal origin in surface and coastal water bodies (Table 2) (Guillaud et al. 1997, Medema et al. 2003). Escherichia coli and Enterococcus sp. can be found in intestinal bacteria of warm-blooded animals. Their presence in coastal waters serve as an indicator of potential sewage pollution. Total coliforms numbers include non-faecal bacteria, so additional testing is often done to confirm the presence and numbers of faecal bacteria. consequence of the vagaries of pathogen detection is the use of normal faecal bacteria as indicators of water pollution (Bettelheim 2003). Escherichia coli is the best bacterial indicator of faecal pollution (Stewart et al. 2008). But faecal enterococci are also used as complementary microbiological water quality indicator (Byamukama et al. 2000). 
Table 1

Description of the coastal beaches of Ghana.

\begin{tabular}{|c|c|c|c|c|c|}
\hline Beaches & $\begin{array}{l}\text { Alternative names } \\
\text { of beaches }\end{array}$ & $\begin{array}{l}\text { Coastal } \\
\text { zone }\end{array}$ & Human activities surrounding the beaches & Coordinates & \\
\hline & & & & Latitude & Longitude \\
\hline $\begin{array}{l}\text { Gh-Côte: Ghana- } \\
\text { Côte d'Ivoire } \\
\text { border }\end{array}$ & $\begin{array}{l}\text { New Town/ Ghana- } \\
\text { Côte d'Ivoire border }\end{array}$ & Western & $\begin{array}{l}\text { Transboundary activities in the western zone, } \\
\text { water transportation, fishing, and domestic }\end{array}$ & $\begin{array}{l}5^{\circ} \\
5.452^{\prime} \mathrm{N}\end{array}$ & $\begin{array}{l}3^{\circ} \\
6.106^{\prime} \mathrm{W}\end{array}$ \\
\hline Domunli & Jerusalem & Western & Domestic and fishing & $\begin{array}{l}5^{\circ} \\
1.372 \mathrm{~N}\end{array}$ & $\begin{array}{l}2^{\circ} \\
45.853^{\prime} \mathrm{W}\end{array}$ \\
\hline Esiama & Esiama-Elimna & Western & Domestic and fishing & $\begin{array}{l}4^{\circ} \\
55.895^{\prime} \mathrm{N}\end{array}$ & $\begin{array}{l}2^{\circ} \\
20.957^{\prime} \mathrm{W}\end{array}$ \\
\hline Aboadzi & $\begin{array}{l}\text { Aboadzi Thermal } \\
\text { Plant }\end{array}$ & Western & $\begin{array}{l}\text { Industrialization, hydrothermal generation, } \\
\text { domestic and fishing }\end{array}$ & $\begin{array}{l}4^{\circ} \\
58.029^{\prime} \mathrm{N}\end{array}$ & $\begin{array}{l}1^{\circ} \\
40.158^{\prime} W\end{array}$ \\
\hline Amisa & $\begin{array}{l}\text { Amissano beach } \\
\text { Amissano village }\end{array}$ & Central & Domestic and fishing & $\begin{array}{l}5^{\circ} \\
12.123^{\prime} \mathrm{N}\end{array}$ & $\begin{array}{l}0^{\circ} \\
59.849 ' \mathrm{~W}\end{array}$ \\
\hline Muni & Apam & Central & Domestic and fishing & $\begin{array}{l}5^{\circ} \\
19.611^{\prime} \mathrm{N}\end{array}$ & $\begin{array}{l}0^{\circ} \\
38.842^{\prime} \mathrm{W}\end{array}$ \\
\hline Densu & Bojo & Central & $\begin{array}{l}\text { Industrialization, Urbanization, domestic, } \\
\text { fishing, Agriculture, Aquaculture, mining }\end{array}$ & $\begin{array}{l}5^{\circ} \\
30.403^{\prime} \mathrm{N}\end{array}$ & $\begin{array}{l}0^{\circ} \\
19.718^{\prime} \mathrm{W}\end{array}$ \\
\hline Kpeshi & La/Laboma & Central & $\begin{array}{l}\text { Industrialization, Urbanization, Tourism, } \\
\text { fishing, and domestic }\end{array}$ & $\begin{array}{l}5^{\circ} \\
33.854^{\prime} \mathrm{N}\end{array}$ & $\begin{array}{l}0^{\circ} \\
8.041^{\prime} \mathrm{W}\end{array}$ \\
\hline Anyanui & Fuvenie & Eastern & Domestic and fishing, water transportation & $\begin{array}{l}5^{\circ} \\
46.372^{\prime} \mathrm{N}\end{array}$ & $\begin{array}{l}0^{\circ} \\
41.785^{\prime} \mathrm{E}\end{array}$ \\
\hline $\begin{array}{l}\text { Gh-Togo: } \\
\text { Ghana-Togo } \\
\text { border }\end{array}$ & $\begin{array}{l}\text { Afloa/Ghana-Togo } \\
\text { border }\end{array}$ & Eastern & $\begin{array}{l}\text { Transboundary activities in the eastern zone; } \\
\text { water transportation, fishing, and domestic }\end{array}$ & $\begin{array}{l}6^{\circ} \\
6.493^{\prime} \mathrm{N}\end{array}$ & $\begin{array}{l}1^{\circ} \\
11.319^{\prime} \mathrm{E}\end{array}$ \\
\hline
\end{tabular}

Escherichia coli and Enterococcus sp. in waters originate from domestic and animals waste discharges (Schroeder \&Wuertz 2003). Waterborne diseases may impact public health (Fong \&Lipp 2005, Mwabi et al. 2012). Bacteria in water is capable of transmitting disease such as cholera, typhoid fever, bacillary dysentery and diarrhea (Cabral 2010, Drasar 2003). The total coliform abundance in water (mean 4,061 $\pm 4,149.14$ ) exceeded the mandatory levels for the water quality for swimming from most countries (Table 3). The mean total coliforms ranged between 1,136 and 1,880 CFU/100 ml, while the faecal coliforms ranged between 336 and $739 \mathrm{CFU} / 100 \mathrm{ml}$. When comparing with WHO standards (WHO 2008) the results suggest that the sanitary quality of the water is unacceptable. The faecal bacteria in coastal waters arise from discharges of untreated sewage or treated sewage effluent, either directly to the sea or via river systems, runoff from adjacent lands, especially from livestock farming (Kay et al. 1999a, Wyer et al. 1998) and faecal inputs from shore birds especially in the intertidal zone (Jones \&Obiri-Danso 1999).

Microbiological water quality shows variation according to the magnitude of such inputs, the flux and dispersion of organisms as a result of near-shore hydrodynamics and the rate of die-off consequences of exposure to UV light (Davies-Colley et al. 1994, Solic \&Krstulovic 1992). Microbial concentrations may differ along a particular stretch of the coast and can exhibit marked temporal fluctuations through the bathing season (Crowther et al. 2001, Kay et al. 1999b, Love et al. 2014, Obiri-Danso \&Jones 1999). Untreated effluents discharges directly onto the coast can contribute to the microorganisms, in seawater and the microbes can be transported via the food chain into the seafood (Haas 2001, Metcalf 1982, Pommepuy et al. 2005). Bacteria pollution may impose potential health hazards and sea food contamination via transfer in the food chain. The presence of pathogenic microorganisms from sewage discharges leads to human and animal related diseases in seawater and seafood. For instance, human enteric viruses such as norovirus, astrovirus, rotavirus, hepatitis Avirus and pathogenic bacteria including Salmonella, Listeria monocytogenes, Shiga-toxin-producing Escherichia coli, Vibrio cholerae, Vibrio parahaemolyticus causing diseases have been associated with faecal contamination in coastal waters (Bosch et al. 2001, Grimes 1991, Kong et al. 2002, Metcalf 1978, Rothenheber 2017). Microorganisms can cause infections such as gastrointestinal and respiratory illnesses, skin diseases and eye infections (Griffin et al. 2003). 


\section{Conclusion}

The coast of Gulf of Guinea, Ghana is faced with environmental problems such as coastal pollution. The survey was conducted to investigate ecological integrity of beach water quality via physical, chemical and microbiological methods. Anyanui beach is characterized by freshwater influence from the Volta River Lake system with the less saline condition, whereas Densu beach exhibited high saline condition. The trophic state of beach waters ranged ultra-oligotrophic to mesotrophic. Muni beach is characterized by low Chl-a concentration, whereas high concentration is found at Ghana-Togo boarder beach. Amisa beach is enriched with high nitrates concentration.

Total coliforms, Escherichia coli and Enterococcus sp. were found in beach waters cross the coast of Ghana but with low concentration at Anyanui beach. Beaches at western coast were less contaminated. Beaches at eastern coast is characterized by moderate contamination. While. beaches at central coast were mostly contaminated with bacteria. The bacteria loads in beach water is fueled significantly $(p<0.05)$ by nitrates and total dissolved solids at most contaminated beaches, Densu and Kpeshi, as demonstrated by principal component analysis and redundancy analyses.

There exists significant $(\mathrm{p}<0.05)$ relationship between bacteria (total coliforms, Escherichia coli and Enterococcus sp.) and physicochemical parameters and among each other. Escherichia coli and Enterococcus sp. are good indicators of faecal contamination of coastal beach waters. The bacteria load in beach waters is a concern for beach swimmers, ecosystems, and public health risk. The study provides a baseline for long-term biomonitoring of coastal waters.

\section{Declarations}

\section{Acknowledgments}

Volkswagen Foundation, Germany, financed the research (Grant No. 89371) to L.G.A. Sincere appreciation to Prof. Dr. Harmut Stuetzel (Leibniz Universität Hannover) with careful scientific mentorship. Profound gratitude to Frau Sylvia Janning (Leibniz Universität Hannover) for providing support with project financial reporting. Special thanks to Dr. John Moisan (The National Aeronautics' and Space Administration) to proofread the manuscript.

\section{Credit authorship contribution statement}

- Dr.. Lailah Gifty Akita: conceptualization, data curation, statistical analyses, fund acquisition, and writing-original draft.

- Dr. Juergen Laudien: conceptualization, fund acquisition, and writing-of review.

- Dr. Charles Biney: conceptualization and writing of the review.

- Mark Akrong: data curation and writing of the review.

\section{Compliance with ethical standards}

Conflict of interest: There is neither conflict nor competing interest between Authors.

Ethical approval: This article does not involve any human participants or animals in the authors' study.

\section{Authors consent to participation in the project research}

The authors were involved in the research participation and writing, and review.

\section{Authors consent to the publication}

The authors have no conflict of interest in the publication of the manuscript.

\section{Funding source}

Volkswagen Foundation, Germany, financed the research to Lailah Gifty Akita, Junior Fellowship grant (Grant No. 89371).

\section{Availability of data and materials}

The data is deposited at PANGAEA and can be made available for public use. 


\section{References}

1. Akita LG, Laudien J, Armah K (2014) Population Dynamics and Ecology of Donax pulchellus and Donax rugosus (Bivalvia: Donacidae) at exposed sandy beaches in Ghana. LAP Lambert Academic Publishing, Germany, 136 pp

2. Allersma E, Tilma MKW (1993) Ocean and Coastal Management. Coastal conditions in West Africa- a review, $199-24$

3. Anita EE, Showell JO (1997) Bacteria Dynamics in Mesotidal Estuaries and Adjoining Nearshore waters, South-east Nigeria. In: Evans SM, Vanderpuye CJ, Armah AK (Hrsg.), The Coastal Zone of West Africa: Problems and Management. Penshaw Press, The Lawns, Undercliff, Cleadon Lane, Cleadon, Sunderland, SR6 7UX, U.K., pp. 246

4. APHA (2012) Standard Methods for Examination of Water and Wastewater. American Public Health Association, Washington, 1360 $\mathrm{pp}$

5. Armah AK (1991) Coastal erosion in Ghana: causes, pattern, research needs and possible solution. Coastal Zone 91:2463-2473

6. Armah AK, Darpaah GA, G. W (1997) Managing the Coast of Ghana: Problems and Options. In: Evans SM, Vanderpuye CJ, Armah AK (Hrsg). Penshaw Press, the Lawns, Undercliff, Cleadon Lane, Cleadon, Sunderland, SR6 7UX, U.K, pp. 426

7. Armah AK, Amlalo DS (1998) Coastal Zone Profile of Ghana. Gulf of Guinea Large Marine Ecosystem Project. Ministry of Environment Science and Technology, Accra-Ghana

8. Bellier E, Grotan V, Engen S, Schartau AK, Diserud OH, Finstad AG (2012) Combining counts and incidence data: an efficient approach for estimating the log-normal species abundance distribution and diversity indices. Oecologia 170, 477 - 88

9. Bettelheim KA (ed) (2003) The genus Escherichia. In: the Prokaryotes: An evolving electronic resource for the microbiological community. Springer-Verlag, New York

10. Biney CA (1982) Preliminary survey of the state of pollution of the coastal environment of Ghana. Oceanologia Acta 4:39-43

11. Biney CA (1993) Coastal zone management in Accra, Reprinted for coastal lines of Western Africa. Proceedings, 8th Symposium on Coastal and Oceans Management, New Orleans, pp. 115-128

12. Biney CA, Asmah R (2010) The effect of physico-chemical parameters on speciation of trace metals in sediments from inland and coastal waters of Ghana. African Journal of Aquatic Science 25:299-305

13. Bosch A, Sanchez G, Le Guyader F, Haugarreau L, Pinto R (2001) Human enteric viruses in Coquina clams associated with large hepatitis A outbreak. Water Science Technology 43:61-65

14. Boyer JN, Kelbe CR, Ortner PB, Rudnick DT (2009) Phytoplankton bloom status: Chlorophylla biomass as an indicator of water quality condition in the southern estuaries of Florida, USA. Ecol Ind 9S:S56-S67

15. Bray JR, Curtis JT (1957) An ordination of the upland forest communities of Southern Wisconsin. Ecol Monogr 27:325-349

16. Bucci AF, Ciotti AM, Pollery RCG, de Carvalho RD, de Albuequerque HCD, Simõn LTS (2012) Temporal variability of chlorophyll-a in the São Vicente Estuary. Brazillian Journal of Oceanography 60:485-499

17. Byamukama D, Kansiime F, Mach RL, Farnleitner AHH (2000) Determination of Escherichia coli contamination with chromocult coliform agar showed a high level of discrimination efficiency for differing faecal pollution levels in tropical waters of Kampala, Uganda. Appl Environ Microbiol 66:864-868

18. Cabral JPS (2010) Water microbiology. Bacterial pathogens and water. International Jornal of Environmental Research Public Health 7:3657-3703

19. Carpenter SR, Caraco NF, Correll DL, Howarth RW, Sharpley AN, Smith VH (1998) Nonpoint pollution of surface waters with phosphorus and nitrogen. Ecol Appl 8:559-568

20. Chapman D (1996) Water Quality Assessment, London

21. Clark RB (2000) Marine Pollution. Clavendon Press, Oxford, 237 pp

22. Correl DL (1998) The role of phosphorus in the eutrophication of receiving waters: a review. J Environ Qual 27:261-266

23. Crowther J, Kay D, Wyer MD (2001) Relationships between microbial water quality and environmental conditions in coastal recreational waters: the fylde coast, UK. Water Res 35:4029-4038

24. Davies-Colley RJ, Bell RG, Donnison AM (1994) Sunlight inactivation of enterococci and faecal coliforms in sewage effluent diluated in seawater. Applieed Environmental Microbiology 600:2049-2058

25. DFID 1999: A Simple Methodology Water Quality Monitoring, Department for International Development Wallingford

26. Drasar SB (ed) (2003) Microbial Flora of the gut. The Handbook of Water and Wastewater Microbiology. Academic Press, London, 99-103 pp 
27. Elser JJ, Bracken MES, Cleland EE, Gruner DS, Harpole WS, Hillebrand H, Smith JE (2007) Global analysis of nitrogen and phosphorus limitation of primary producers in freshwater, marine and terrestrial ecosystems. Ecological Letters 10:1135-1142

28. Ferretti JA, Tran HV, Cosgrove E, Protonentis J, Loftin V, Conklin CS, Grant RN (2011) Comparison of Enterococcus density estimates in marine beach and bay samples by real-time polymerase chain reaction, membrane filtration, and defined substrate testing. Mar Pollut Bull 62:1066-1072

29. Fong T-T, Lipp EK (2005) Enteric viruses of humans and animals in aquatic environments: health risks, detection, and potential water quality assessment tools. Microbiol Mol Biol Rev 69:357-371

30. Griffin DW, Donaldson KA, Paul JH, Rose JB (2003) Pathogenic human Viruses in coastal waters. 16, 129-143

31. Grimes DJ (1991) Ecology of estuarine bacteria capable of causing human disease: A review. Estuaries 14:345-360

32. Guillaud JF, Derrien A, Gourmelon M, Pommepuy M (1997) T90 as a tool for engineers: interest and limits. Water Science Technology 35:277-281

33. Haas CN (2001) Comment on "estimating the infection risk in recreational waters from the faecal indicator concentration and from the ration between pathogens and indicator". Water Res 35:3280-3281

34. HACH 2012: Water Analysis Handbook, Hach Company, Loveland, Colorado, USA

35. Hammer $\varnothing$, Harper DAT, Ryan PD (2001) PAST: Palaeontological statistics software package for education and data analysis. Palaeontologia Electronica 4:9

36. Haugland RA, Siefring SC, Wymer LJ, Brenner KP, Dufour AP (2005) Comparison of Enterococcus measurements in freshwater at two recreational beaches by quantitative polymerase chain reaction and member filter culture analysis. Water Res 39:559-568

37. Hinga KR, Jeon H, Lewis NF (1995) Marine Eutrophication Review Part 1: Quantifying the Effects of Nitrogen Enrichment on Phytoplankton in Coastal Ecosystems. NOAA Coast Ocean Office, Silver spring

38. Igobinosa EO, Okoh Al (2009) Impact of discharge wastewater effluents on the physico-chemical qualities of a recieving watershed in a typical rural community. International Journal of Environment Science Technology 6:175-182

39. Jaji MO, Bamgbose O, Odukoya OO, Arowlo TA (2007) Water quality assessment of Ogun River, south west Nigeria. Environmental Monitoring Assessment 133:447-482

40. Jamshidi S, Bukar MNB, Yousefi M (2010) Concentration of chlorophyll-a in coastal waters of Rudsar. Res J Environ Sci 4:383-391

41. Jamshidi S, Abu Bakar NB (2011) A study on distribution of chlorophll-a in the coastal waters of Anzali Port, south Caspian Sea. Ocean Sci Discuss 8:435-451

42. Jones K, Obiri-Danso K (1999) Non-compliance of beaches with the EU directives of bathing wate quality: evidence of non-point sources of pollution in Morecambe Bay. Journal of Applied Microbiology Symposium Supplementary 85, 101S-107S

43. Kay D, Wyer MD, Crowther J, O'Neill G, Jackson GF, Fleisher JM (1999a) Faecal indicators impact on recreational waters: budget studies and diffuse source modelling Journal of Applied Microbiology Symposium Supplementary 85, 70S-82S

44. Kay D, Wyer MD, Crowther J, O'Neill G, Jackson GF, Fleisher JM, Fewtrell L (eds) (1999b) Changing standards and catachment sources of faecal indicators in near shore bathing waters. Wate Quality-Processes and Policy. Wiley, New York, 47-64 pp

45. Kennish MJ (2001) Environmental threats and environmental future of estuaries. Environ Conserv 29:78-107

46. Kinnear PR, Gray CD (1999) SPSS for Windows Made Simple. Psychology Press Ltd, Hove

47. Kong RYC, Lee SKY, Law TWF, Law SHW, Wu RSS (2002) Rapid detection of six types of bacterial pathogens in marine water by multiplex PCR. Water Res 36:2802-2812

48. Lamptey E, Armah AK, Allotey LC (2010) Spatial Assemblages of Tropical Interidal Rocky Shore Communities in Ghana, West Africa. Nova Science Publishers, Inc, New York, 52 pp

49. Lastra M, de la Huz R, Sanchez-Mata AG, Rodil IF, Aerts K, Beloso S, Lopez J (2006) Ecology of exposed sandy beaches in northern Spain: Environmental factors controlling macrofauna communities. J Sea Res 55:128-140

50. Lawson ET (2014) When rhetoric meets reality: attitude change and coastal zone management in Ghana. Environment Naural Nesources Research 4:37-50

51. Leech NL, Barrett KC, Morgan GA (2011) IBM SPSS for Introductory statistics: Use and interpretation. Routledge -Taylor \& Francis Group, New York

52. Legendre P, Gallagher ED (2001) Ecologically meaningful transformations for ordination of species data. Oecologia 129:271-280 
53. Lorenzen CJ (1967) Determination of chlorophyll and pheo-pigments: spectrophotometric equations. Limnological Oceanography $12: 343$

54. Love DC, Rodriguez RA, Gibbons CD, Griffith JF, Yu Q, Stewart JR, Sobsey MD (2014) Human viruses and viral indicators in marine water at two recreational beaches in Southern California, USA. Journal of Water Health 12:136-150

55. Ly CK (1980) The role of the Akosombo dam on the Volta River in causing coastal erosion in central and eastern Ghana (West Africa). Mar Geol 37:323-332

56. Medema GJ, Payment P, Dufour A, Robertson W, Waite M, Hunter P, Kirby R, Anderson Y (2003) Safe drinking water: an ongoing challenge. In: assessing microbial safety of drinking water. Improving approaches and method. WHO \& OECD, IWA Publishing, London, pp 11-45

57. Mensah MA, Anang E (eds) (1998) The State of the coastal and marine environment of Ghana. The state of coastal and marine environmental of the Gulf of Guinea, 69-74 pp

58. Metcalf TG (ed) (1978) Indicators of viruses in shellfish. Indicators and Viruses in Water and Food. Ann Harbor Science, Ann Harbor, $383-415 \mathrm{pp}$

59. Metcalf TG (1982) Virus in shellfish-growing waters. Environmental International 7:21-27

60. Millipore (1991) Water microbiology. laboratories and field procedures, Bedford, M.A., 32 pp

61. Möller WAA, Scharf BW (1986) The content of chlorophyll-a in the sediment of the volcanic maar lakes in the Eifel region (Germany) as an indicator for eutrophication. Hydrobiologia 143:327-329

62. Monbet Y (1992) Control of phytoplankton biomass in estuaries: A comparative analysis of microtidal and macrotidal estuaries. Estuareies 15:563-571

63. Mwabi JK, Mamba BB, Momba MNB (2012) Removal of Escherichia coli and Faecal Coliforms from Surface Water and Groundwater by Household Water Treatment Devices/Systems: A Sustainable Solution for Improving Water Quality in Rural Communities of the Southern African Development Community Region. International Journal of Environmental Research Public Health 9:139-170

64. Nixon SW (1995) Coastal Marine Eutrophication - a Definition, Social Causes, and Future Concerns. Ophelia 41:199-219

65. Obiri-Danso K, Jones K (1999) The effect of a new sewage treatment plant on faecal indicator numbers, campylobacters and bathing water compliance in Morecambe Bay. J Appl Microbiol 86:603-614

66. Odonkor ST, Ampofo JK (2013) Escherichia coli as an indicator of bacteriological quality of water: an overview. Microbiology Research 4

67. Omoike Al, Vanloon GW (1999) Removal of phosphorus and organic matter removal by alum during wastewater treatment. Water Res 33:3617-3627

68. Pachepsky A, Shelton DR (2011) Escherichia Coli and Fecal Coliforms in Freshwater and Estuarine Sediments. Critical Reviews in Environmental Science Technology 41:1067-1110

69. Paerl HW, Huisman J (2008) Blooms like it hot. Science 320:57-58

70. Paerl HW, Xu H, McCarthy MJ, Zhu G, Qin B, Li Y, Gardner WS (2011) Controlling harmful cyanobacterial blooms in a hyper-eutrophic lake (Lake Taihu, China): the need for a dual nutrient (N \& P) management strategy. Water Res 45:1973-1983

71. Pommepuy M, Hervio-Heath D, Caprais MP, Gourmelon M, Le Saux JC, Le Guyader F (2005) Fecal contamination in coastal areas: An engineering approach. Pathogens in the Marine Environment, Oceans

72. Belkin, Colwell, Springer, New York, pp. 331-359

73. Rothenheber D (2017) Microbial source tracking in coastal recreational waters of southern maine: relationship between enterrococci, environmental factors, potential pathogens ad fecal sources, University of Maine

74. Saad MAH, Younes WAN (2006) Role of phosphorus and nitrogenous species in water quality of a coastal Egyptian heavily polluted Mediterranean basin. International Journal of Oceans Oceanography 1:1-19

75. Savage WG (1905) Bacteriological examination of tidal mud as an index of pollution of the river. Journal of Hygiene 5:146-174

76. Sayler GS, Nelson JDJ, Justice A, Colwell RR (1975) Distribution and significance of fecal indicator organisms in the Upper Chesapeake Bay. Appl Microbiol 30:625-638

77. Schroeder ED, Wuertz S (eds) (2003) Bacteria. The Handbook of Water and Wastewater Microbiology. Academic Press, London, 57$112 \mathrm{pp}$

Page $12 / 17$ 
78. Sharpley AN, Jarvie HP, Buda A, May L, Spears B, Kleinman P (2013) Phosphorus legacy: Overcoming the effets of past management practices to mitigate future water quality impairment. J Environ Qual 42:1308-1326

79. Shuval H (ed) (2006) Thalassogenic infectious diseases caused by wastewater pollution of the marine enviornment. Oceans and Health: Pathogens in the Marine Environment. Springer, New York, 373-389 pp

80. Šmilauer P, Lepš J (2014) Multivariate analysis of ecological data using CANOCO 5. Cambridge University Press, Cambridge

81. Smith VH, Schindler DW (2009) Eutrophication science: where do we go from here? Trends in Ecological Evolution 24:201-207

82. Solic M, Krstulovic N (1992) Seperate and combined effects of solar radiation, temperature, salinity and pH on the survival of faecal coliforms in sea water. Mar Pollut Bull 24:411-416

83. Solo-Gabriele HM, Wolfert MA, Desmarais TR, Palmer CJ (2000) Sources of Escherichia coli in a coastal subtropical environment. Appl Environ Microbiol 66:230-237

84. Stewart MR, Gast RJ, Fujioka RS, Solo-Gabriele HM, Meschke SJ, Amaral-Zettler LA, Del Castillo E, Polz MF, Collier TK, Strom MS, Sinigalliano CD, Moeller PD, Holland AF (2008) The coastal environment and human health: microbial indicators, pathogens, sentinels and reservoirs. Envrnmental Health: A Global Access Science Source S3, 1-4

85. Stumn W, Morgan JJ (1981) Aquatic chemistry, John Wiley and Sons, 780 pp

86. ter Braak CJF, Verdonschot PFM (1995) Canonical correspondence-analysis and related multivariate methods in aquatic ecology. Aquat Sci 57:255-289

87. Tripathy SC, Ray AK, Patra S, Sarma VV (2005) Water quality assessment of Gautami- Godavari mangroves estuarine ecosystem of Andhra Pradesh, India during Septemeber 2001. J Earth Syst Sci 114:185-190

88. UNESCO (1994) Protocols for the Joint Global Ocean Flux Study (J GOFS) Core Measurements, Manual and Guide

89. USEPA (2002) Method 1600: Enterococci in water by membrane filtration using membrane-Enterococcus indoxyl-D-glucoside agar (mEI),, US Environmental Protection Agency, USEPA, Office of Water (4303T), Washington, DC

90. Wellman S, Redden A, Rissik D, Scanes P (2002) Phytoplankton production in near-pristine and urban-influenced coastal lagoons, Proceedings of the annual conference of the Australian Marine Sciences Association, 10-12 July, Fremantle WA

91. Welschmeyer NA (1994) Analysis of chlorophyll $a$ in the presence of chlorophyll $b$ and pheopigments. Limnol Oceanogr 39:1-7

92. Wetzel RG (2001) Limnology: Lake and Rivers Ecosytems. Academic Press, San Diego

93. WHO (2008) Guidelines for Drinking-water Quality, Incorporating 1st and 2nd Agenda, vol 1. World Health Organization, Geneva, Switzerland, Recommendations

94. Wiafe G, Boateng I, Appeaning-Addo K, Quashigah PN, Ababio SD, Sowah L (2013) Handbook of Coastal Process and Management in Ghana. The Choir Press, The Coastal Processes Research Group, 254 pp

95. Wintermans JFM, De Mots AS (1965) Spectrophotometeric characteristics of chlorophylls a and $b$ and their phaeophytins in ethanol. Biochimica et al Biophysica Acta (BBA) 109:448-453

96. Wyer MD, Kay D, Crowther J, Whittaker J, Spence A, Huen V, Wilson C, Carbo P, Newsome J (1998) Faecal-indicator budgets for recreational coastal waters: a catchment approach. Journal Chartered Institute of Water Environmental Management 12:414-424

\section{Figures}




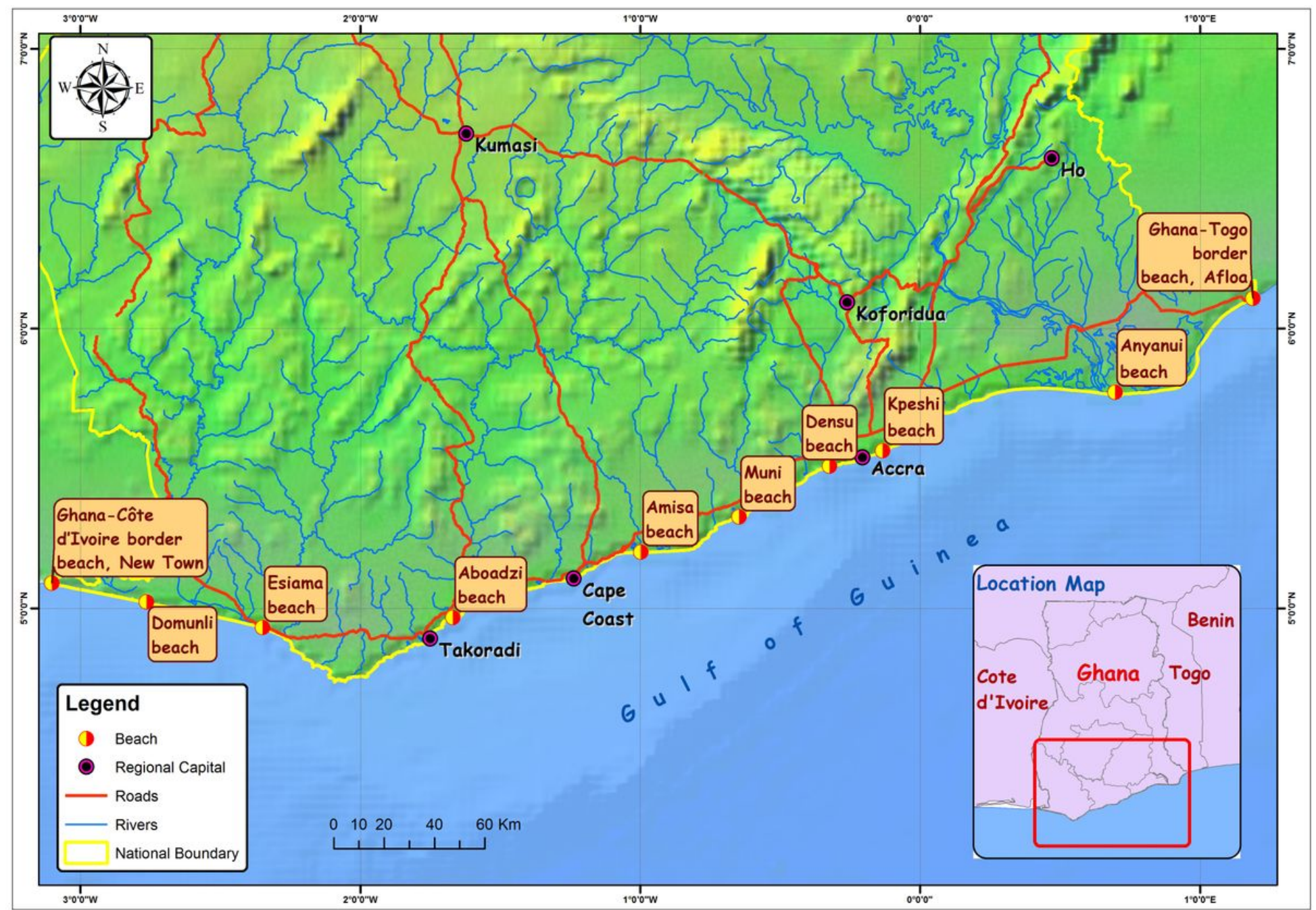

Figure 1

A map of sampled ten selected coastal beaches in Ghana. 


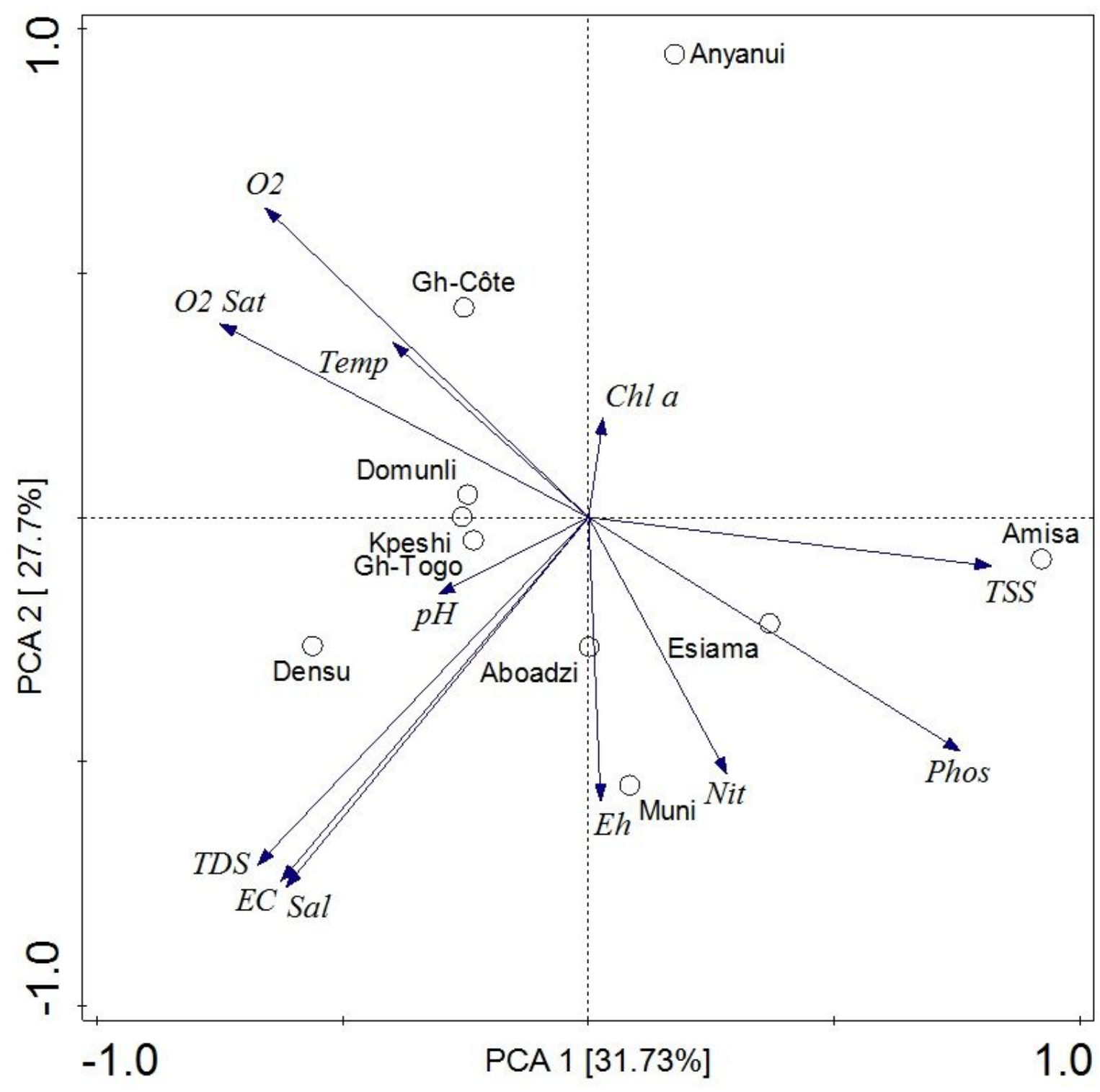

Figure 2

Principal component analysis (PCA) of a grouping of beaches (circles) based on physicochemical variables (blue arrows). The long arrows show the most influential physicochemical for the group of beaches. The PCA diagram with the first axis (31.73\%) of the horizontal and the second axis (27.7\%) of the vertical. The orientations of these arrows indicate the correlation of these variables in PCA ordination axes. 


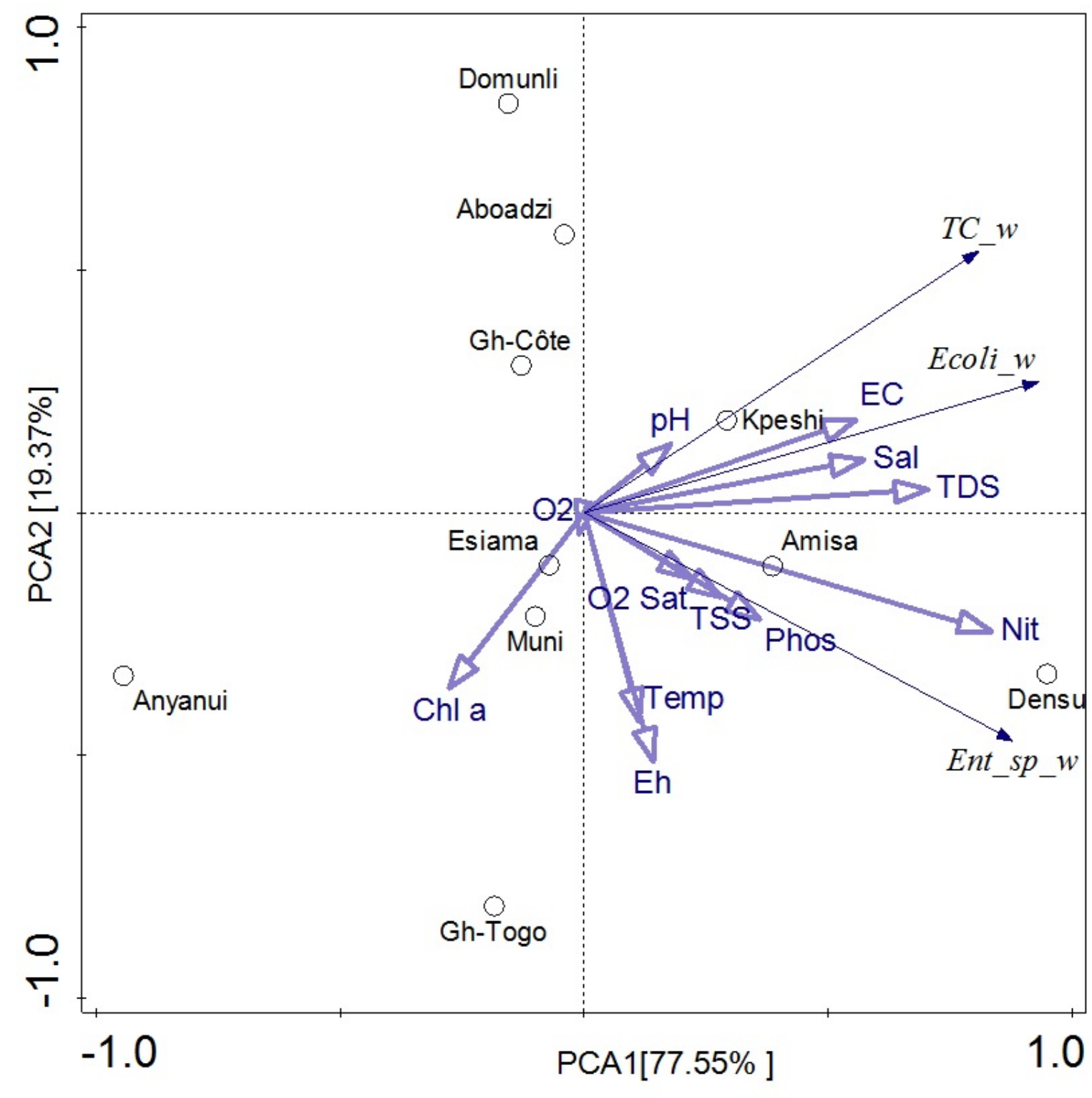

Figure 3

Principal component analysis (PCA) ordination of integrated physicochemical (thick violent arrows) and bacteria data (thin blue arrows) (triangles). The long arrow indicates most influential environmental variables at beaches, mainly total dissolved solids, nitrates, and bacteria loads. 


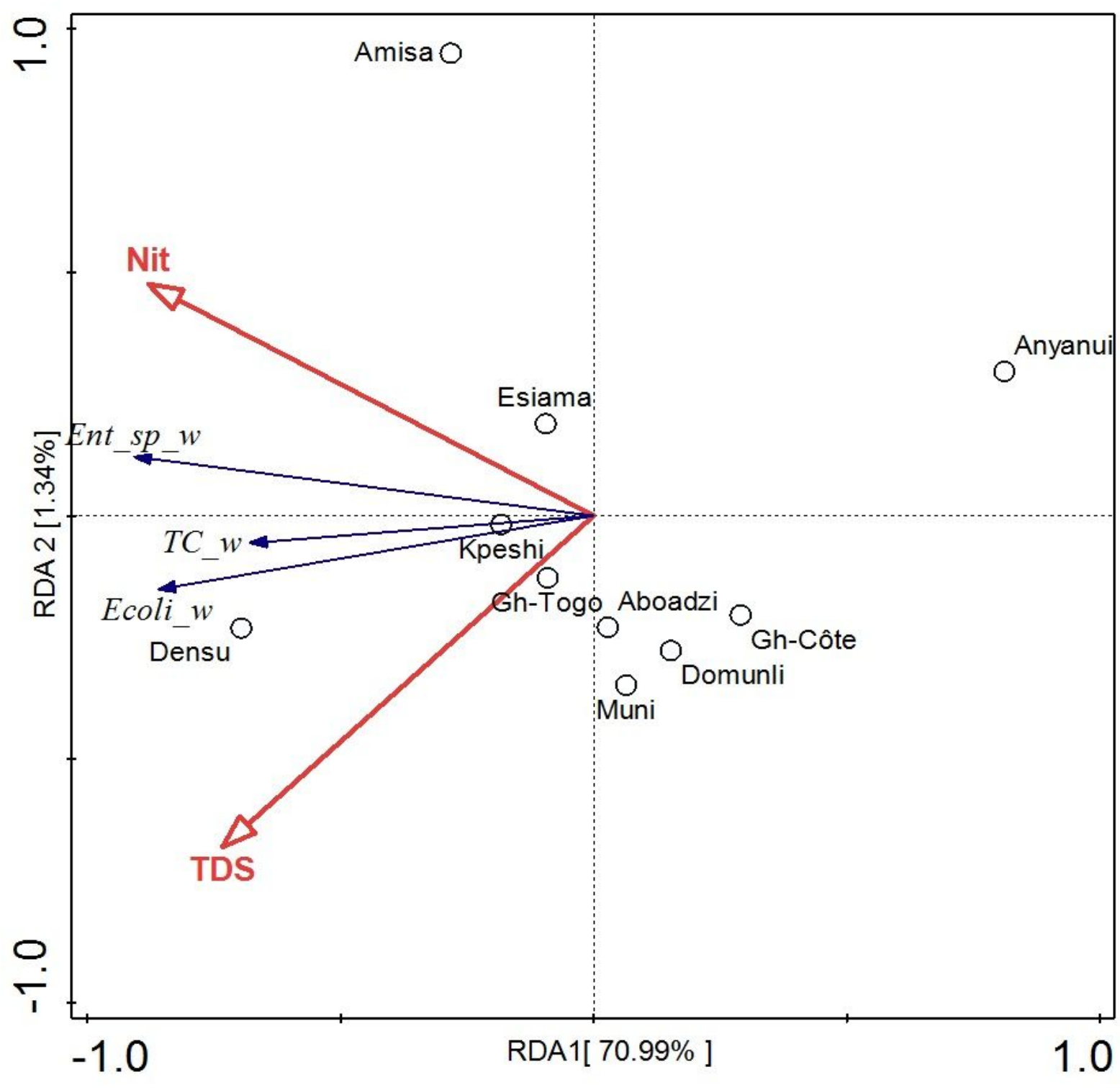

Figure 4

Redundancy analysis (RDA) diagram of the best environmental variables (red arrows) selected by the forward selection procedure influencing the bacteria (blue arrows) data within the studied beaches. The ordination diagram with the first axis (horizontal) and the third (vertical) axis of distance-based constrained.

\section{Supplementary Files}

This is a list of supplementary files associated with this preprint. Click to download.

- AkitaetalAppendix29thDec20.docx 